University of Montana

ScholarWorks at University of Montana

2008

\title{
Tree Species Control Rates of Free-Living Nitrogen Fixation in a Tropical Rain Forest
}

Sasha C. Reed

Cory C. Cleveland

The University of Montana, cory.cleveland@umontana.edu

Alan R. Townsend

Follow this and additional works at: https://scholarworks.umt.edu/decs_pubs

Part of the Ecology and Evolutionary Biology Commons Let us know how access to this document benefits you.

\section{Recommended Citation}

Reed, Sasha C.; Cleveland, Cory C.; and Townsend, Alan R., "Tree Species Control Rates of Free-Living Nitrogen Fixation in a Tropical Rain Forest" (2008). Ecosystem and Conservation Sciences Faculty Publications. 14.

https://scholarworks.umt.edu/decs_pubs/14

This Article is brought to you for free and open access by the Ecosystem and Conservation Sciences at ScholarWorks at University of Montana. It has been accepted for inclusion in Ecosystem and Conservation Sciences Faculty Publications by an authorized administrator of ScholarWorks at University of Montana. For more information, please contact scholarworks@mso.umt.edu. 


\title{
TREE SPECIES CONTROL RATES OF FREE-LIVING NITROGEN FIXATION IN A TROPICAL RAIN FOREST
}

\author{
Sasha C. Reed, ${ }^{1,3}$ Cory C. Cleveleland, ${ }^{2}$ and Alan R. Townsend ${ }^{1}$ \\ ${ }^{1}$ INSTAAR and Department of Ecology and Evolutionary Biology, University of Colorado, Boulder, Colorado 80309 USA \\ ${ }^{2}$ College of Forestry and Conservation, University of Montana, Missoula, Montana 59812 USA
}

\begin{abstract}
Tropical rain forests represent some of the most diverse ecosystems on earth, yet mechanistic links between tree species identity and ecosystem function in these forests remains poorly understood. Here, using free-living nitrogen $(\mathrm{N})$ fixation as a model, we explore the idea that interspecies variation in canopy nutrient concentrations may drive significant local-scale variation in biogeochemical processes. Biological $\mathrm{N}$ fixation is the largest "natural" source of newly available $\mathrm{N}$ to terrestrial ecosystems, and estimates suggest the highest such inputs occur in tropical ecosystems. While patterns of and controls over $\mathrm{N}$ fixation in these systems remain poorly known, the data we do have suggest that chemical differences among tree species canopies could affect free-living $\mathrm{N}$ fixation rates. In a diverse lowland rain forest in Costa Rica, we established a series of vertical, canopy-to-soil profiles for six common canopy tree species, and we measured free-living $\mathrm{N}$ fixation rates and multiple aspects of chemistry of live canopy leaves, senesced canopy leaves, bulk leaf litter, and soil for eight individuals of each tree species. Free-living $\mathrm{N}$ fixation rates varied significantly among tree species for all four components, and independent of species identity, rates of $\mathrm{N}$ fixation ranged by orders of magnitude along the vertical profile. Our data suggest that variations in phosphorus $(\mathrm{P})$ concentration drove a significant fraction of the observed species-specific variation in free-living $\mathrm{N}$ fixation rates within each layer of the vertical profile. Furthermore, our data suggest significant links between canopy and forest floor nutrient concentrations; canopy $\mathrm{P}$ was correlated with bulk leaf litter $\mathrm{P}$ below individual tree crowns. Thus, canopy chemistry may affect a suite of ecosystem processes not only within the canopy itself, but at and beneath the forest floor as well.
\end{abstract}

Key words: Costa Rica; ecosystem function; free-living; nitrogen fixation; phosphorus; tree species; tropical rain forest.

\section{INTRODUCTION}

Nitrogen $(\mathrm{N})$ supply exerts strong control over the composition, diversity and productivity of many ecosystems (Vitousek and Howarth 1991, Vitousek et al. 1997), and biological $\mathrm{N}$ fixation represents the largest natural source of newly available $\mathrm{N}$ to the terrestrial biosphere (Galloway et al. 1995, Vitousek et al. 1997). Yet, as with many other ecosystem processes (e.g., Clark 2007), our understanding of the ecological controls over $\mathrm{N}$ fixation remains incomplete in tropical forests (Vitousek et al. 2002). Given current and projected changes to these ecosystems (Clark 2007), including rapidly rising deposition of anthropogenic $\mathrm{N}$ (Galloway et al. 2004), the importance of unraveling controls over the tropical $\mathrm{N}$ cycle is high (Matson et al. 2002). However, in many ways, the $\mathrm{N}$ cycle of tropical forests presents some unique puzzles.

For example, in large portions of the tropical forest biome, $\mathrm{N}$ availability may exceed $\mathrm{N}$ demand (e.g.,

Manuscript received 31 August 2007; revised 6 February 2008; accepted 28 February 2008. Corresponding Editor: M. A. Arthur.

${ }^{3}$ E-mail: sasha.reed@colorado.edu
Martinelli et al. 1999), yet $\mathrm{N}$ fixation rates there are suggested to be among the highest on earth (Cleveland et al. 1999). The seemingly paradoxical observation of elevated rates of high-cost $\mathrm{N}$ inputs in ecosystems that are not limited by $\mathrm{N}$ underscores our incomplete understanding of $\mathrm{N}$ fixation controls, and extends to two distinct processes: symbiotic and free-living $\mathrm{N}$ fixation (Sprent and Sprent 1990). The former is confined to specific plant taxa and, although an interesting debate revolves around the prevalence of leguminous $\mathrm{N}$ fixation in tropical rain forests (Crews 1999, Gehring et al. 2005), here we focus on the freeliving $\mathrm{N}$ fixation occurring in the canopy, litter layer and soils of forests with or without legumes. Data suggest that free-living $\mathrm{N}$ fixation may represent substantial inputs of $\mathrm{N}$ to tropical forest ecosystems (Jordan et al. 1982, Maheswaran and Gunatilleke 1990, Cleveland et al. 1999, Reed et al. 2007), and may be subject to controls that vary in concert with attributes unique to individual tree species.

Multiple factors have been proposed as possible controls over free-living $\mathrm{N}$ fixation in natural systems. These include preferential predation on $\mathrm{N}$-fixing organisms, micronutrient availability (Vitousek and Howarth 1991; principally Mo), temperature (Hicks et al. 2003), 
moisture (Roskoski 1980), and, in particular, energy and macronutrient availability (particularly $\mathrm{N}$ and phosphorus; Richards 1973, Remacle 1977, Silvester 1978, Eisele et al. 1989, Crews et al. 2000, Vitousek and Hobbie 2000, Benner et al. 2007, Reed et al. 2007). Even at the local scale, tropical forests display substantial interspecific variation in the $\mathrm{N}$ and phosphorus $(\mathrm{P})$ content of live and senesced leaves (Townsend et al. 2007). Similarly, dissolved organic matter (DOM) leached from leaves on the forest floor (Neff et al. 2003, Cleveland and Townsend 2006) can be an important source of energy and nutrients for microbial communities in tropical forests (Cleveland et al. 2004), and both the amount of DOM produced, and its nutrient content, vary significantly between tree species (Cleveland et al. 2004). Thus, the potential clearly exists for tropical tree species to regulate free-living $\mathrm{N}$ fixation through interspecies differences in foliar carbon (C), N and $\mathrm{P}$ availability. Yet, to our knowledge, there are no published studies addressing how and why rates of free-living $\mathrm{N}$ fixation vary within and beneath the crowns of individual tree species in a tropical forest.

Here, we used 48 trees (eight individuals each of six tree species) within a mature tropical rain forest to explore species effects on free-living $\mathrm{N}$ fixation rates from the canopy to the soil (see Plate 1), and to concurrently assess local-scale variation in foliar and soil chemistry. We hypothesized that (1) regardless of species identity, rates of free-living $\mathrm{N}$ fixation would vary significantly along a vertical profile that included sunlit canopy leaves, recently senesced canopy leaves, bulk forest floor litter and surface soils; (2) within profile layers, live and senesced canopy leaf $\mathrm{N}$ fixation rates would be dependent upon species identity, while bulk leaf litter and soil rates would not vary significantly by tree species; and (3) any observed species-specificity in $\mathrm{N}$ fixation rates would relate to species differences in foliar or soil P content.

\section{Materials ANd Methods}

\section{Site description}

The study site is a mature, lowland tropical wet forest (sensu Holdridge et al. 1971) located in the Golfo Dulce Forest Reserve on the Osa Peninsula in southwest Costa Rica $\left(8^{\circ} 43^{\prime} \mathrm{N}, 83^{\circ} 37^{\prime} \mathrm{W}\right)$. Mean annual temperature averages $26^{\circ} \pm 1.5^{\circ} \mathrm{C}$ (mean $\pm \mathrm{SD}$ ), rainfall averages $>5000 \mathrm{~mm} / \mathrm{yr}$, and soil at the site is characterized as a Ppoor Ultisol (Berrange and Thorpe 1988, Bern et al. 2005). The site is a stratified, closed canopy, highly diverse (100-200 tree species/ha [Kappelle et al. 2002]) rain forest that includes many common Neotropical tree species (e.g., Brosimum utile Kunth Oken. [Moraceae]; Caryocar costaricense Donn. Sm. [Caryocaraceae]; Hieronyma alchorneoides Fr. Allem [Phyllanthaceae]; Schizolobium parahybum Vell. S.F. Blake [Fabaceae]; and Vantanea barbourii Standl. [Humiriaceae]). The lowland rain forests of the Osa Peninsula house $\sim 57$ tree families ( $\sim 260$ tree species), including all three subfam-

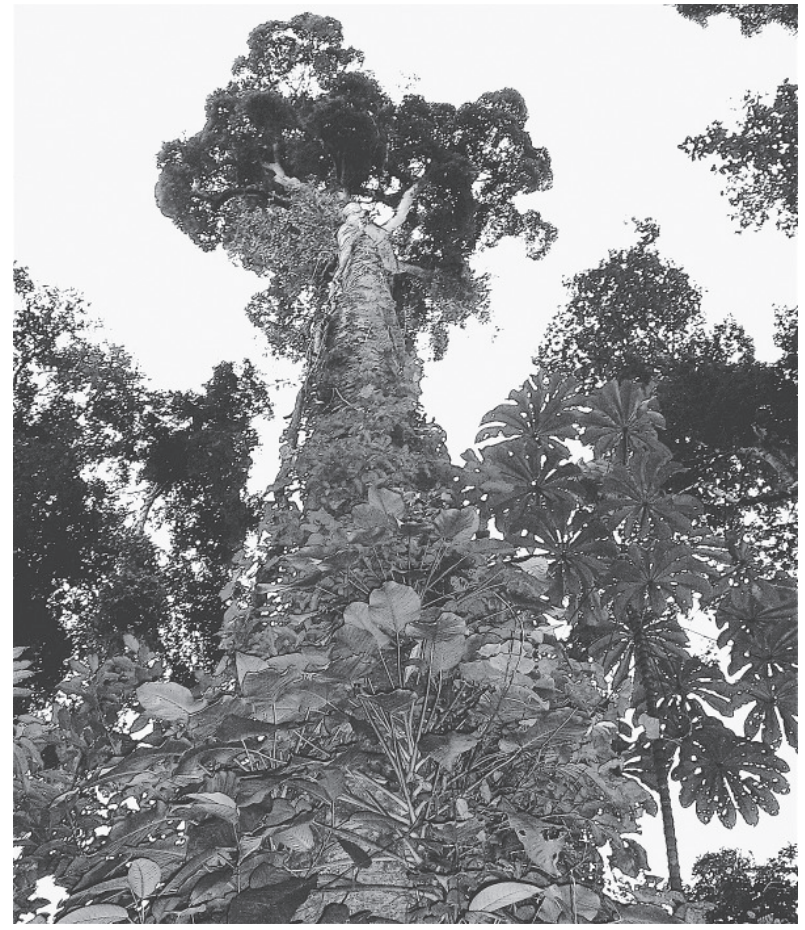

Plate 1. The high tree diversity of many tropical forests creates the potential for substantial local-scale gradients in likely controls over biogeochemical processes. This study investigated how free-living nitrogen fixation rates vary among different canopy tree species, and along vertical profiles from canopy leaves to surface soils. Photo credit: S. C. Reed.

ilies of Fabaceae (i.e., Caesalpiniodeae, Mimosoideae, and Papilionoideae [Hartshorn and Poveda 1983, Kappelle et al. 2002]). Comprehensive data on relative abundance of tree species are not available in the region, but in our study site, no single species makes up a dominant fraction of the canopy and overall diversity is exceptionally high.

\section{Experimental design}

We investigated species-level patterns and controls over free-living $\mathrm{N}$ fixation by collecting samples from four layers within a vertical, canopy-to-soil profile (Plate 1). Eight individuals each of six tree species (48 trees total; Table 1) were sampled in June of 2006. The six species we selected are among the more common species in our study sites, represent six common Neotropical families, and had significant and known (Townsend et al. 2007) differences in canopy $\mathrm{N}$ and $\mathrm{P}$ content. From each of the 48 individual trees, we collected (1) live canopy leaves; (2) recently senesced canopy leaves; (3) bulk leaf litter leaves; and (4) topsoil $(0-2 \mathrm{~cm}$ depth). Rates of free-living $\mathrm{N}$ fixation and multiple aspects of chemistry were measured for all samples, allowing comparisons both along a forest vertical profile and among tree species within each layer of the profile. We note that some of the organisms we group here as "free-living" may be symbiotic, such as canopy lichens, and we use the term to draw a clear 
TABLE 1. Chemical characteristics (means with SE in parentheses) of the canopy leaves, litter trap leaves, bulk leaf litter, and soil from six tropical tree species.

\begin{tabular}{|c|c|c|c|c|c|c|c|}
\hline Tree species & utile & costaricense & staminodella & paraensis & parahybum & globulifera & $P$ \\
\hline Genus & Brosimum & Caryocar & Manilkara & Qualea & Schizolobium & Symphonia & \\
\hline Family & Moraceae & Caryocaraceae & Sapotaceae & Vochysiaceae & Fabaceae & Clusiaceae & \\
\hline Identity & [Kunth] Oken. & Don & Gil & Du & $\begin{array}{c}\text { [Vell.] S.F. } \\
\text { Blake }\end{array}$ & L.f. & \\
\hline \multicolumn{8}{|l|}{ Canopy leaves } \\
\hline$\% \mathrm{C}$ & $46.18^{\mathrm{a}, \mathrm{b}}(0.77)$ & $47.94^{\mathrm{a}}(0.88)$ & $44.69^{\mathrm{b}}(0.63)$ & $40.01^{\mathrm{c}}(1.43)$ & $46.46^{\mathrm{a}, \mathrm{b}}(0.80)$ & $48.76^{\mathrm{a}}(0.32)$ & $<0.001$ \\
\hline$\% \mathrm{~N}$ & $1.38^{\mathrm{a}}(0.09)$ & $1.49^{\mathrm{a}}(0.04)$ & $1.25^{\mathrm{a}}(0.06)$ & $1.22^{\mathrm{a}}(0.11)$ & $2.00^{\mathrm{b}}(0.14)$ & $1.54^{\mathrm{a}, \mathrm{b}}(0.10)$ & $<0.001$ \\
\hline$\% \mathrm{P}$ & $0.11^{\mathrm{a}, \mathrm{b}}(0.02)$ & $0.13^{\mathrm{a}, \mathrm{b}}(0.02)$ & $0.08^{\mathrm{b}}(0.01)$ & $0.07^{\mathrm{b}}(0.01)$ & $0.18^{\mathrm{a}}(0.03)$ & $0.11^{\mathrm{a}, \mathrm{b}}(0.02)$ & 0.003 \\
\hline$\%$ lignin & $20.02^{\mathrm{d}}(0.90)$ & $15.49^{\mathrm{a}, \mathrm{c}}(2.06)$ & $19.32^{\mathrm{a}, \mathrm{c}}(1.37)$ & $14.08^{\mathrm{c}}(1.35)$ & $14.56^{\mathrm{b}, \mathrm{c}, \mathrm{d}}(0.92)$ & $42.86^{\mathrm{a}, \mathrm{c}}(1.08)$ & $<0.001$ \\
\hline \multicolumn{8}{|l|}{ Litter trap leaves } \\
\hline$\% \mathrm{C}$ & $45.32^{\mathrm{a}, \mathrm{b}, \mathrm{c}}(0.99)$ & $46.20^{\mathrm{a}}(0.62)$ & $49.91^{\mathrm{b}}(1.74)$ & $41.37^{\mathrm{c}}(1.29)$ & $46.20^{\mathrm{a}, \mathrm{b}, \mathrm{c}}(0.62)$ & $50.07^{\mathrm{a}}(1.71)$ & $<0.001$ \\
\hline$\% \mathrm{~N}$ & $1.18^{\mathrm{a}, \mathrm{c}, \mathrm{d}, \mathrm{e}}(0.05)$ & $1.14^{\mathrm{a}, \mathrm{d}}(0.15)$ & $0.92^{\mathrm{e}}(0.03)$ & $0.86^{\mathrm{d}}(0.07)$ & $1.74^{\mathrm{b}}(0.11)$ & $1.66^{\mathrm{b}, \mathrm{c}}(0.11)$ & $<0.001$ \\
\hline$\% \mathrm{P}$ & $0.08^{\mathrm{a}, \mathrm{e}}(0.01)$ & $0.09^{\mathrm{a}}(0.01)$ & $0.02^{\mathrm{b}}(0.01)$ & $0.04^{\mathrm{b}, \mathrm{e}}(0.01)$ & $0.15^{\mathrm{c}, \mathrm{d}}(0.02)$ & $0.10^{\mathrm{a}, \mathrm{c}}(0.01)$ & $<0.001$ \\
\hline$\%$ lignin & $49.80^{\mathrm{c}}(3.08)$ & $26.47^{\mathrm{b}}(3.41)$ & & $15.97^{\mathrm{a}}(0.77)$ & $63.47^{\mathrm{b}}(2.02)$ & $32.67^{\mathrm{b}, \mathrm{c}}(3.42)$ & $<0.001$ \\
\hline \multicolumn{8}{|l|}{ Bulk leaf litter } \\
\hline$\% \mathrm{C}$ & $44.74(1.40)$ & $44.58(0.44)$ & $46.19(0.91)$ & $41.71(1.26)$ & $44.55(0.98)$ & $46.03(1.52)$ & 0.112 \\
\hline$\% \mathrm{~N}$ & $1.71^{\mathrm{a}}(0.16)$ & $1.44^{\mathrm{a}, \mathrm{b}}(0.14)$ & $1.11^{\mathrm{a}, \mathrm{b}}(0.06)$ & $1.01^{\mathrm{b}}(0.08)$ & $1.47^{\mathrm{a}, \mathrm{b}}(0.19)$ & $1.53^{\mathrm{a}, \mathrm{b}}(0.18)$ & 0.022 \\
\hline$\% \mathrm{P}$ & $0.17^{\mathrm{a}}(0.05)$ & $0.11^{\mathrm{a}}(0.01)$ & $0.06^{\mathrm{b}, \mathrm{c}}(0.02)$ & $0.05^{\mathrm{c}}(0.01)$ & $0.09^{\mathrm{a}, \mathrm{b}}(0.01)$ & $0.10^{\mathrm{a}, \mathrm{b}}(0.01)$ & $<0.001$ \\
\hline$\%$ lignin & $47.8(1.80)$ & $42.1(0.74)$ & $27.91(8.18)$ & $30.12(0.96)$ & $41.44(6.6)$ & $37.81(6.96)$ & 0.310 \\
\hline \multicolumn{8}{|l|}{ Soil } \\
\hline TOC $(\mu \mathrm{g} / \mathrm{g})$ & $762.2^{\mathrm{a}, \mathrm{b}}(88.5)$ & $431.1^{\mathrm{a}}(38.1)$ & $750.6^{\mathrm{a}, \mathrm{b}}(62.2)$ & $898.9^{\mathrm{b}}(176.9)$ & $762.2^{\mathrm{a}, \mathrm{b}}(83.5)$ & $820.4^{\mathrm{a}, \mathrm{b}}(122.1)$ & 0.038 \\
\hline TDN & $278.7(63.0)$ & $106.4(9.6)$ & $193.6(24.0)$ & $268.2(82.4)$ & $154.0(55.4)$ & $188.5(55.4)$ & 0.200 \\
\hline Labile $P(\mu \mathrm{g} / \mathrm{g})$ & $48.4^{\mathrm{c}}(4.92)$ & $44.4^{\mathrm{a}, \mathrm{c}, \mathrm{d}}(3.74)$ & $23.8^{\mathrm{b}}(3.03)$ & $27.7^{\mathrm{b}, \mathrm{d}}(4.58)$ & $37.2^{\mathrm{a}, \mathrm{b}, \mathrm{c}}(4.04)$ & $45.3^{\mathrm{a}, \mathrm{c}, \mathrm{d}}(5.55)$ & $<0.001$ \\
\hline
\end{tabular}

Notes: Significant differences among species within a row are denoted by a $P$ value $<0.05$ and by different lowercase letters. Lignin data were not available for the $M$. staminodella litter trap leaves.

distinction from the microorganisms that live in a structured symbiosis within leguminous plant roots.

\section{Sample collection}

From each of the 48 trees, we collected four sets of samples from vertical forest transects. First, live canopy leaves were collected using a 12-gauge shotgun; sunlit leaves were shot from the canopy of each tree and caught by hand as they fell to the ground. Next, to collect recently senesced canopy leaves from individual trees, $2.25-\mathrm{m}^{2}$ litter traps were constructed and placed next to each tree 5 days before collection, and speciesspecific leaves were separated from the bulk material collected over the 5-day period. Third, bulk leaf litter was hand-collected beneath the crown of each of the 48 trees using a stratified random design within a $4 \mathrm{~m}$ radius of the base of each tree. Finally, soils (overlying leaf litter removed) were sampled within the same treespecific spheres to a depth of $2 \mathrm{~cm}$; all soils were collected as intact soil cores using $55 \mathrm{~mL}, 2.54 \mathrm{~cm}$ diameter, clear acrylic tubes.

All samples were analyzed for $\mathrm{N}$ fixation rates on the day they were collected and, for each of the layers of the vertical profile, all species were collected on the same day. Samples collected from different layers of the profile were collected and analyzed on successive days (excepting leaf litter and soil, which were collected and analyzed on the same day), and each layer of the profile from a specific tree was sampled once. Canopy and senesced leaves were misted with $1 \mathrm{~mL}$ of deionized water before analysis; leaf litter and soil moistures were not manipulated. From all trees, two sets of foliar samples (canopy leaves, senesced leaves, and leaf litter) were collected for $\mathrm{N}$ fixation rate analysis: the first set was incubated in situ on the forest floor, while the second set was incubated under elevated photosynthetically active radiation (PAR) conditions $(\sim 450$ $\left.\mu \mathrm{mol} \cdot \mathrm{m}^{-2} \cdot \mathrm{s}\right)$ using light boxes. Thus, each tree was assessed using seven samples: two sets of canopy leaves (one forest floor and one elevated PAR), two sets of senesced leaves (one forest floor and one elevated PAR), two sets of bulk leaf litter (one forest floor and one elevated PAR), and a single soil sample.

\section{Foliar analyses}

All foliage and litter samples were air dried, ground to a fine powder using a mortar and pestle, oven-dried at $70^{\circ} \mathrm{C}$ for $48 \mathrm{~h}$, and analyzed for total $\mathrm{C}$ and $\mathrm{N}$ using a Carlo Erba EA 1110 elemental analyzer (CE Elantech, Lakewood, New Jersey, USA). Foliar P was analyzed using a concentrated sulfuric acid/hydrogen peroxide digest and an ascorbic acid molybdate colorimetric analysis (Kuo 1996) on an Alpkem autoanalyzer (OI Analytical, College Station, Texas, USA). We also used a plant tissue analyzer (Ankom Technology, Macedon, New York, USA) to further characterize litter and foliar $\mathrm{C}$ composition. Briefly, samples were ground to a fine powder, sealed into digest bags (Ankom Technology, Macedon, New York, USA), subjected to a series of digestions, and dried at $70^{\circ} \mathrm{C}$ and weighed between digestions to determine the fraction of organic material represented by (1) soluble cell contents; (2) hemicellulose 


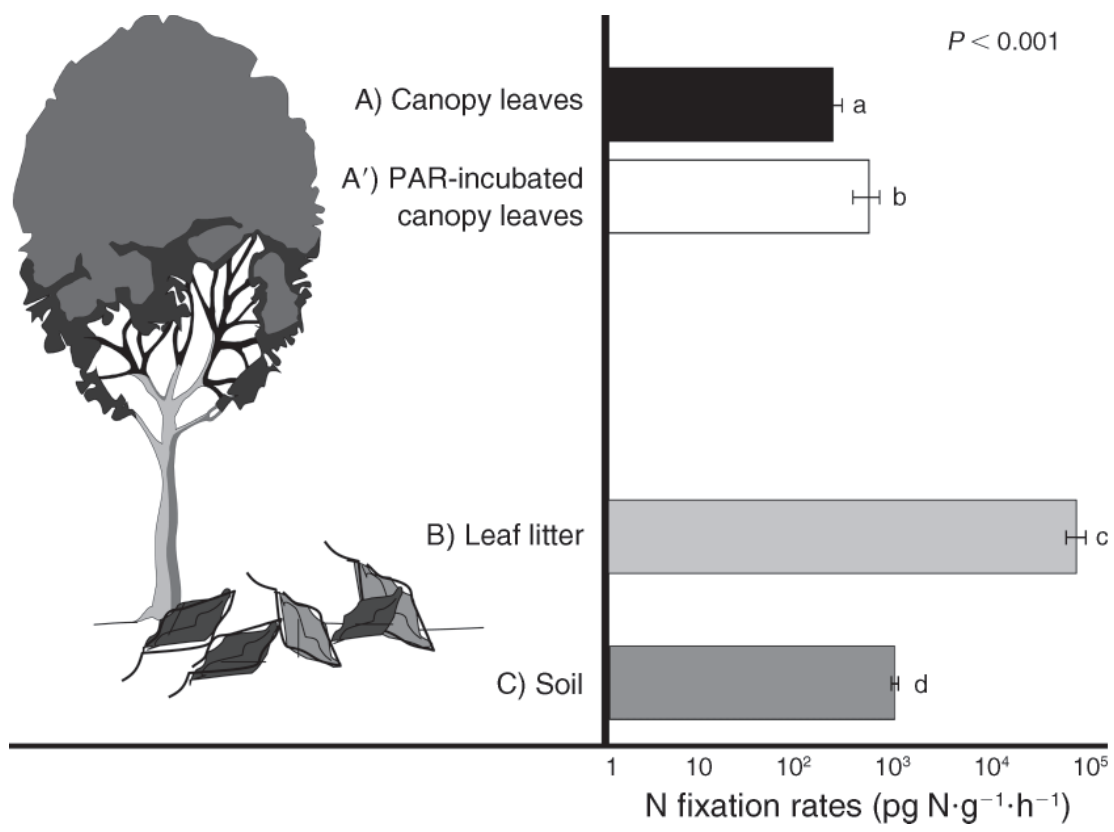

FIG. 1. Rates of free-living $\mathrm{N}$ fixation along a rain forest vertical profile: (A) sunlit canopy leaves, $\left(\mathrm{A}^{\prime}\right)$ sunlit canopy leaves incubated under elevated photosynthetically active radiation (PAR), (B) mixed-species leaf litter, and (C) topsoil $(0-2 \mathrm{~cm})$. Nitrogen fixation rates $\left(\mathrm{pg} \cdot \mathrm{g}^{-1} \cdot \mathrm{h}^{-1}\right)$ varied along the vertical profile $(P<0.001)$, and means $(n \approx 48$ trees per layer $) \pm \mathrm{SE}$ are presented on a logarithmic scale $(x$-axis). Significant differences $(P<0.05)$ in $\mathrm{N}$ fixation rates among groups are denoted by different lowercase letters.

and bound proteins; (3) cellulose; and (4) lignin and other recalcitrants (Hobbie and Gough 2004).

Previous research in this site (Cleveland et al. 2004) and others (Kalbitz et al. 2000) has shown that variations in the chemistry of DOM leached from plant material can strongly influence soil processes. To identify potential links between DOM chemistry and rates of free-living $\mathrm{N}$ fixation, dry foliage, and leaf litter from each tree species was leached in $125 \mathrm{~mL}$ of deionized water for $10 \mathrm{hr}$. Samples were then filtered using Whatman $\mathrm{GF} / \mathrm{F}$ glass fiber filters (Whatman International, Springfield Mill, UK), and total organic $\mathrm{C}$ (TOC) and total dissolved $\mathrm{N}$ (TDN) were determined using a Shimadzu TOC-Vcpn/TN-1 (Shimadzu Corporation, Kyoto, Japan). Total dissolved $\mathrm{P}$ in leachates was analyzed colorimetrically using a concentrated sulfuric acid/hydrogen peroxide digest and an ascorbic acid molybdate colorimetric analysis (Kuo 1996) on an Alpkem autoanalyzer.

\section{Soil analyses}

Soil samples were sieved to $4 \mathrm{~mm}$, oven-dried at $70^{\circ} \mathrm{C}$ for $48 \mathrm{~h}$, and analyzed for total soil $\mathrm{C}$ and $\mathrm{N}$ using a Carlo Erba EA 1110 elemental analyzer. Soil soluble C and nutrient concentrations were determined using fresh soils and a $2 \mathrm{M} \mathrm{KCl}$ extraction (Robertson et al. 1999); DOC and TDN concentrations in extracted samples were determined using a Shimadzu TOC-Vcpn/TN-1. Extractable ammonium $\left(\mathrm{NH}_{4}{ }^{+}\right)$and nitrate $\left(\mathrm{NO}_{3}{ }^{-}\right)$ concentrations were determined using an Alpkem autoanalyzer, and soil labile $\mathrm{P}$ (defined as the sum of resin- and total bicarbonate-extractable $\mathrm{P}$ [Bowman et al. 1978]) was determined using a resin and a $0.5 \mathrm{~mol} / \mathrm{L}$ sodium bicarbonate extraction (Tiessen and Moir 1993). Phosphorus concentrations in the extractants were measured colorimetrically using an ascorbic acid molybdate colorimetric analysis (Kuo 1996) on an Alpkem autoanalyzer.

\section{Acetylene reduction assay}

We used the acetylene reduction assay (ARA; Belnap 1996) to determine rates of free-living $\mathrm{N}$ fixation in plant and soil samples. Each sample $(\sim 1 \mathrm{~g}$ of foliage or $\sim 10 \mathrm{~g}$ of soil) was sealed into $55-\mathrm{mL}$ clear acrylic tubes, injected with enough acetylene to create a $10 \%$ headspace concentration by volume (through a lid fitted with a septum), and vented to the atmosphere to equilibrate pressure in the tubes. All samples were incubated for 16 hours in situ on the forest floor, receiving ambient forest floor light and temperatures in both daylight and nighttime hours. To assess if light played a role in regulating rates of $\mathrm{N}$ fixation, a parallel set of foliar samples was incubated under elevated (relative to the forest floor) PAR conditions $(\sim 450$ $\left.\mu \mathrm{mol} \cdot \mathrm{m}^{-2} \cdot \mathrm{s}^{-1}\right)$. After incubation, sample headspaces were mixed, subsampled, injected into pre-purged Vacutainer tubes (Becton, Dickinson and Company, Franklin Lakes, New Jersey, USA), and returned to the laboratory for analysis. 
In the laboratory, ethylene concentrations were measured using a Shimadzu 14-A Gas Chromatograph equipped with a flame ionization detector $\left(330^{\circ} \mathrm{C}\right)$ and a Poropak N column $\left(110^{\circ} \mathrm{C}\right.$; Supelco, Bellefonte, Pennsylvania, USA). Acetylene blanks (no leaves, no soil) were collected during the field incubation and used to assess background levels of ethylene in the acetylene gas. Background ethylene concentrations made up a small percentage of the ethylene produced for senesced leaves, leaf litter and soil, but because of low rates (Fig. 1), did comprise a significant percentage of the ethylene produced by canopy leaves. However, blank ethylene concentrations were quite consistent $(<3 \%$ variation among tubes), and the average background ethylene value was subtracted from all sample values before analysis. Controls for ethylene production and consumption in the absence of acetylene were also determined and were consistently small compared with ethylene production rates. All sample dry masses and moisture contents were determined gravimetrically after oven drying for $48 \mathrm{~h}$ at $70^{\circ} \mathrm{C}$. Rates of acetylene reduction were calculated using the unit nanomoles $\left(10^{-9} \mathrm{~mol}\right)$ of acetylene reduced per gram dry mass of sample per hour of incubation.

\section{$N$ fixation rate estimates}

Studies of $\mathrm{N}$ fixation often extrapolate acetylene reduction rates to annual $\mathrm{N}$ fixation rates $\left(\mathrm{kg} \cdot \mathrm{ha}^{-1} \cdot \mathrm{yr}^{-1}\right)$ to facilitate comparison across sites and with other components of the $\mathrm{N}$ cycle. Thus, in addition to hourly rates reported here, all rates of acetylene reduction were converted to annual rates of $\mathrm{N}$ fixation. We note that these extrapolations stem from a single sampling event and should not be considered definitive annual rates; however, the rates reported here do match well with annual leaf litter and soil estimates assessed throughout the year at the same site (Reed et al. 2007). The relationship between acetylene reduction rates and $\mathrm{N}$ fixation rates has been calculated using ${ }^{15} \mathrm{~N}$ techniques and can be variable (Ley and D'Antonio 1998), but often the relationship is near the theoretical range of 3 moles of acetylene reduced for every one mole of $\mathrm{N}$ fixed (Hardy et al. 1968, Vitousek 1994, Vitousek and Hobbie 2000). Thus, we applied the theoretical conversion ratio of 3:1 for all rate conversions.

Soil samples were collected as $2 \mathrm{~cm}$ intact cores, and were converted to the more commonly reported $10 \mathrm{~cm}$ depth, area-based rates $\left(\mathrm{kg} \cdot \mathrm{ha}^{-1} \cdot \mathrm{yr}^{-1}\right)$. Previous research has shown free-living $\mathrm{N}$ fixation rates in forest soils to be dominated by the activity of heterotrophic organisms (Sprent and Sprent 1990, Reed 2007), and N fixation rates can remain relatively constant along a $0-10 \mathrm{~cm}$ soil profile (Kreibich 2002). However, we note that this extrapolation is particularly tenuous, as other studies suggest that $\mathrm{N}$ fixation rates can decrease exponentially along a soil profile (Kreibich and Kern 2003), and as soil $\mathrm{N}$ fixation occurs below depths of $10 \mathrm{~cm}$ (Kreibich 2002).
Nitrogen fixation rates for live canopy leaves were converted from mass-based rates $\left(\mathrm{kg} \cdot \mathrm{g}^{-1} \cdot \mathrm{yr}^{-1}\right)$ to areabased rates $\left(\mathrm{kg} \cdot \mathrm{ha}^{-1} \cdot \mathrm{yr}^{-1}\right)$ using a mass-to-area conversion factor determined separately for each species. Briefly, the area of multiple leaves from each species was determined using a LI-COR 3000A portable leaf area meter (LI-COR Biosciences, Lincoln, Nebraska, USA). Leaves were then weighed and these data were used to determine a specific mass-to-area relationship for each tree species. A typical leaf area index (LAI) of 6 (based on previous research in moist tropical forests; Asner et al. 2003) was then used to convert rates for individual leaves $\left(\mathrm{kg} \cdot \mathrm{cm}^{-2} \cdot \mathrm{yr}^{-1}\right)$ to area-based rates for the forest canopy $\left(\mathrm{kg} \cdot \mathrm{ha}^{-1} \cdot \mathrm{yr}^{-1}\right)$. To calculate area-based rates for leaf litter, we used a leaf litter weight-to-area conversion factor determined in the field at the time of sample collection. Briefly, a $0.25-\mathrm{m}^{2}$ template was placed on the forest floor and all leaf litter beneath the template was collected, dried, and weighed. The process was repeated multiple times across the forest and was found to produce a consistent mass-to-area relationship. Areabased $\mathrm{N}$ fixation rates for litter trap samples were not calculated.

\section{Statistical analyses}

All data were tested for normality and homoscedasticity (using Levene's test for the equality of variances); if either assumption was violated, data were lntransformed before analysis (SPSS 11.0.4, Chicago, Illinois, USA). Differences among rates of $\mathrm{N}$ fixation and among chemical properties, both along the vertical forest profile and between species within a profile layer, were determined using one-way analyses of variance (ANOVA). To examine variation along the vertical profile, data were grouped by position in the profile and species identity was ignored. To explore variation among tree species, data were analyzed separately for each layer of the profile and data were grouped according to species identity. Multiple comparisons (for each ANOVA) were analyzed using Tukey's post hoc analysis. Relationships between rates of $\mathrm{N}$ fixation and leaf or soil chemistry were determined using regression analyses. Tree species "footprints" of $\mathrm{N}$ fixation rates and chemical properties along the vertical profile were investigated using two-tailed bivariate correlation analyses. For all data, significance was determined at $\alpha=0.05$.

\section{Results}

\section{Variability along the vertical profile}

Rates of free-living $\mathrm{N}$ fixation varied significantly along the vertical forest profile, and in general, rates increased from the top of the canopy to the forest floor (Fig. 1). On a mass basis, canopy leaves (as a group) had the lowest rates of $\mathrm{N}$ fixation $\left(0.21 \pm 0.05 \mathrm{ng} \cdot \mathrm{g}^{-1} \cdot \mathrm{h}^{-1}\right.$ $[$ mean $\pm \mathrm{SE}]$ ), soils and recently senesced leaves had intermediate rates $(0.74 \pm 0.09$ and $1.70 \pm 0.64$ $\mathrm{ng} \cdot \mathrm{g}^{-1} \cdot \mathrm{h}^{-1}$, respectively), and bulk leaf litter collected 
from the forest floor had the highest rates $(52.04 \pm 13.51$ $\mathrm{ng} \cdot \mathrm{g}^{-1} \cdot \mathrm{h}^{-1}$; Fig. 1). In foliar samples, total $\mathrm{P}$ and $\mathrm{N}$ varied significantly along the vertical gradient $(P<0.01$ for each): Canopy leaves had significantly higher concentrations of total $\mathrm{P}(1120.8 \pm 87.8 \mu \mathrm{g} \mathrm{P} / \mathrm{g})$ than litter trap leaves $(819.3 \pm 77.0 \mu \mathrm{g} \mathrm{P} / \mathrm{g})$ or bulk leaf litter (861.9 $\pm 55.8 \mu \mathrm{g} \mathrm{P} / \mathrm{g}$ ), and canopy leaves were significantly higher $(1.49 \pm 0.06 \% \mathrm{~N})$ in $\mathrm{N}$ than litter trap leaves $(1.22 \% \pm 0.07 \% \mathrm{~N})$, but neither were significantly different from bulk leaf litter $(1.39 \% \pm$ $0.07 \% \mathrm{~N})$. Total C concentrations did not vary significantly along the vertical profile.

Other aspects of foliar chemical composition also varied along the vertical gradient. For example, when plant samples were grouped according to vertical position, the fraction of soluble organic material was significantly higher $(P=0.004)$ in canopy leaves $(46.8 \%$ $\pm 2.0 \%)$ than in litter trap leaves $(37.6 \% \pm 3.7 \%)$ and leaf litter leaves $(33.9 \% \pm 2.2 \%)$. In contrast, the relative proportion of lignin was lowest in canopy leaves $(21.1 \%$ $\pm 2.1 \%)$ and was significantly higher $(P<0.001)$ in litter trap $(36.0 \% \pm 4.0 \%)$ and leaf litter leaves $(37.0 \% \pm$ $2.8 \%$; Table 1). Finally, water-extractable DOC concentrations also varied along the vertical profile. As a group, canopy leaves produced significantly $(P=0.043)$ more DOC $(111.2 \pm 28.7 \mathrm{mg} / \mathrm{g})$ than litter trap leaves $(41.6 \pm 6.9 \mathrm{mg} / \mathrm{g})$ or bulk litter $(44.2 \pm 7.4 \mathrm{mg} / \mathrm{g})$. However, neither TDN nor total dissolved P concentrations in leaf leachate varied significantly along the profile.

\section{Species-specific variability}

Profile position represents one potential source of variability in $\mathrm{N}$ fixation rates in this diverse forest, but our data also showed substantial species-level variability in foliar and soil chemistry and $\mathrm{N}$ fixation rates. For each of the four vertical layers along the canopy-to-soil gradient, rates of free-living $\mathrm{N}$ fixation varied significantly by tree species (Fig. 2; litter trap data not shown, $P=0.015)$. Species-specific variations in $\mathrm{N}$ fixation rates corresponded with changes in foliar chemistry (Table 1); for example, total $\mathrm{C}$, total $\mathrm{N}$, and total $\mathrm{P}$ concentrations of canopy leaves varied significantly among the six tree species, as did the proportion of soluble leaf material and lignin concentrations (Table 1). Similarly, total C, total $\mathrm{N}$, total $\mathrm{P}$, and lignin concentrations varied significantly among species in litter trap leaf samples $(P<0.001$ for each), as did total $\mathrm{P}$ and $\mathrm{N}$ for bulk leaf litter (Table 1). The total dissolved $\mathrm{P}$ concentrations of foliar leachate also consistently varied between species in canopy leaves, litter trap leaves, and leaf litter leaves $(P$ $<0.05, P<0.001$, and $P<0.001$, respectively). Furthermore, soil organic $\mathrm{C}(P<0.05)$ and soil labile $\mathrm{P}$ $(P<0.001)$ varied significantly between species (Table 1). Percent moisture values were not significantly different among species for canopy leaves, senesced leaves, leaf litter, or soil.

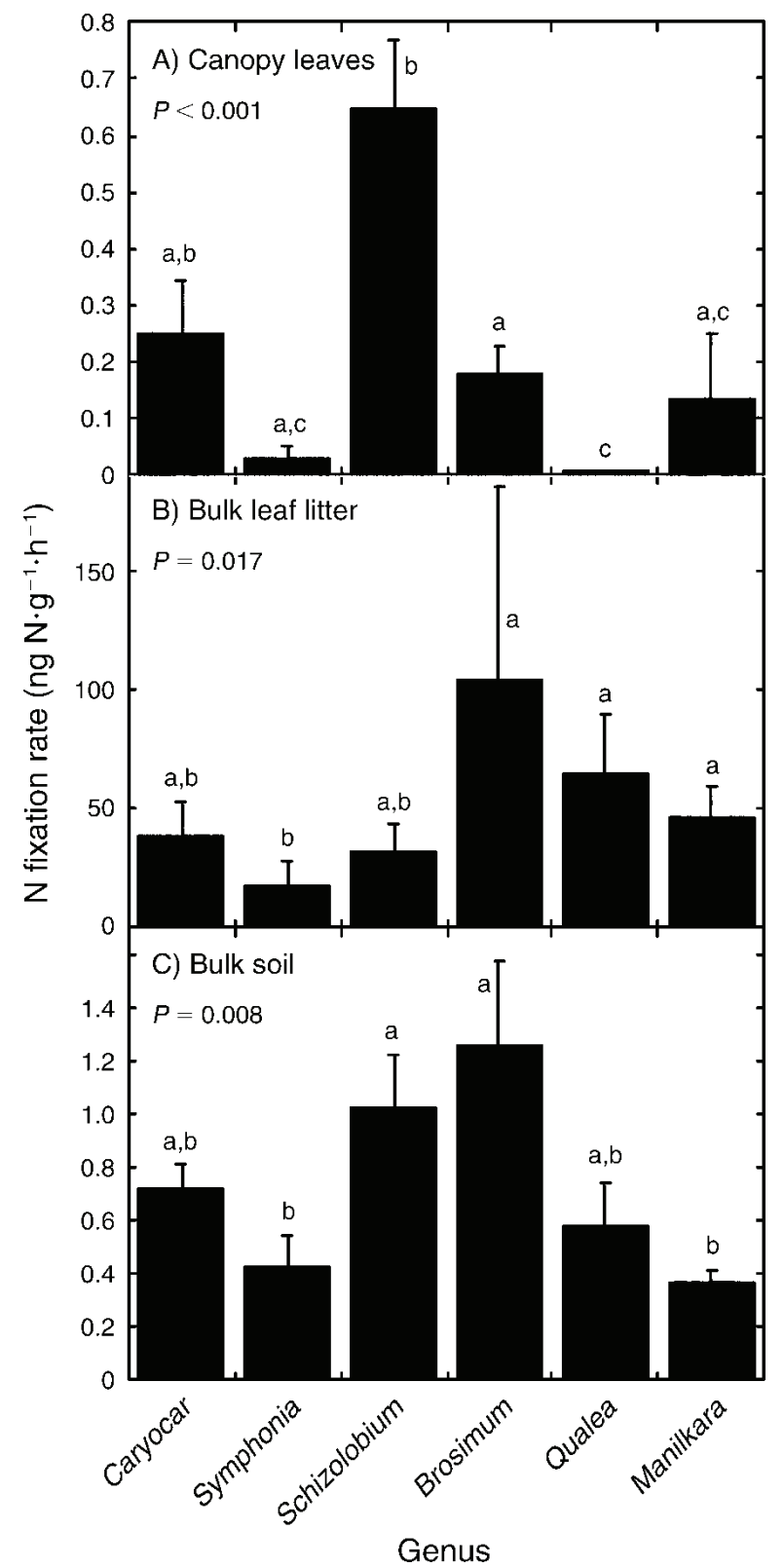

FIG. 2. Comparisons of free-living $\mathrm{N}$ fixation rates among six tree species incubated on the forest floor for (A) sunlit canopy leaves, (B) mixed-species bulk leaf litter, and (C) surface soil $(0-2 \mathrm{~cm})$ collected within the crown radius of trees. Freeliving $\mathrm{N}$ fixation rates were significantly different among the six tree species within each forest component ( $P<0.05$ for each), and significant differences among species within a component are denoted by different lowercase letters. $\mathrm{N}$ fixation rates $\left(\right.$ ng $\left.\cdot \mathrm{g}^{-1} \cdot \mathrm{h}^{-1}\right)$ are means $(n \geq 7$ trees per species for each layer $) \pm$ SE. Note that the $y$-axis scale is different for each component.

\section{$N$ fixation rate controls}

Differences in sample chemistry did not explain observed differences in $\mathrm{N}$ fixation rates along the vertical profile. However, within each layer of the profile, variation in total $\mathrm{P}$ was significantly related to variation in $\mathrm{N}$ fixation rates for canopy leaves $(P<$ 0.001; Fig. 3), senesced leaves $(P<0.001)$, and bulk leaf 

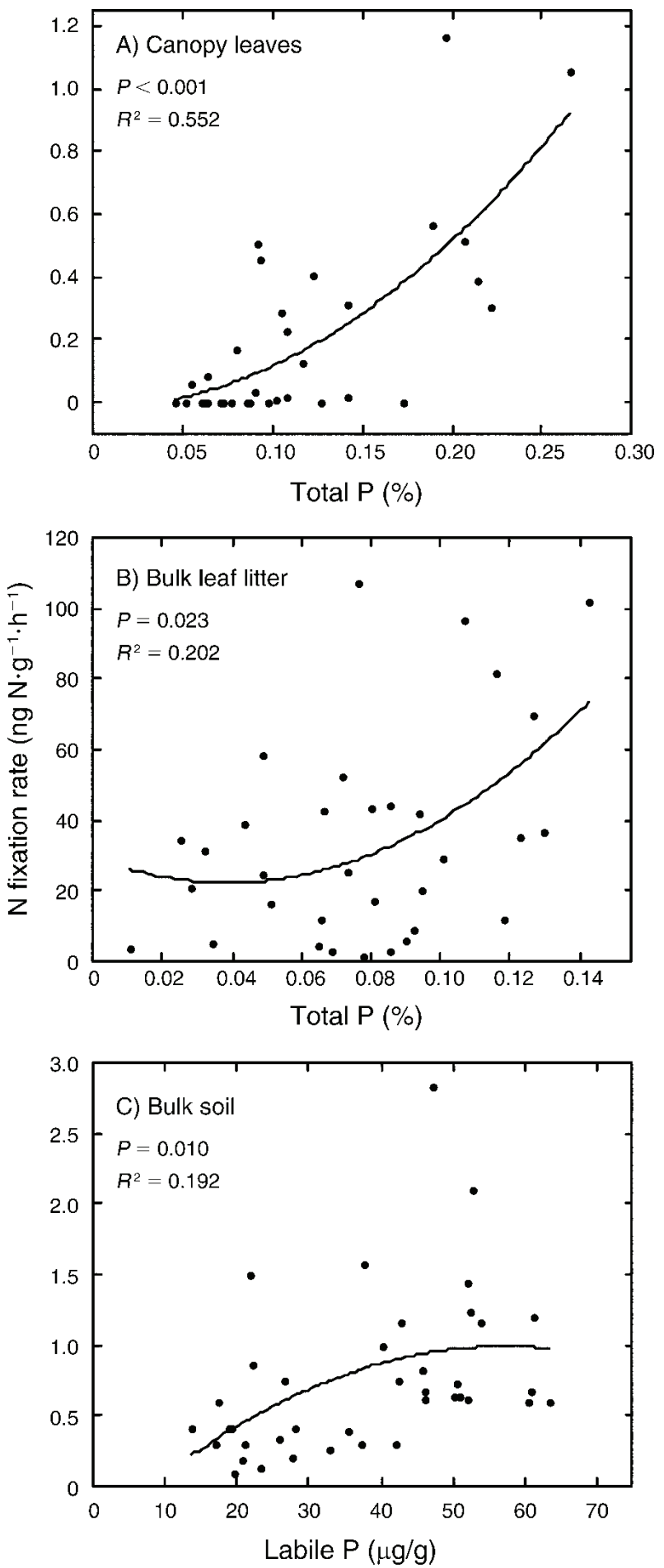

FIG. 3. Relationships between $\mathrm{P}$ concentration and $\mathrm{N}$ fixation rate for (A) sunlit canopy leaves, (B) mixed-species leaf litter, and (C) topsoil $(0-2 \mathrm{~cm})$. Significance and $R^{2}$ values from regression analyses are shown for each component. Note that the $x$ - and $y$-axis scales differ among components.

litter $(P=0.023$; Fig. 3$)$, and variation in labile soil $\mathrm{P}$ was significantly related with variation in soil $\mathrm{N}$ fixation rates $(P=0.010$; Fig. 3). Furthermore, for both canopy and freshly senesced leaves, dissolved $P$ in leaf leachate
$(P<0.001, R=0.477$ canopy $P=0.010, R=0.494$ senesced) significantly related to $\mathrm{N}$ fixation rates.

Soil moisture correlated positively with rates of soil $\mathrm{N}$ fixation, though the percent moistures of canopy leaves, senesced litter trap leaves, and leaf litter were not related to associated $\mathrm{N}$ fixation rates. Thus, although soil moisture did not vary significantly by tree species, variation in soil moisture was suggested to partially control rates of soil $\mathrm{N}$ fixation, an observation that has been made previously at this site (Reed et al. 2007).

\section{Tree species footprints}

The species-specific differences in $\mathrm{P}$ concentrations from canopy to soil suggested a species-generated $\mathrm{P}$ "footprint" that spanned the vertical profile. Total $\mathrm{P}$ in canopy leaves correlated with that of not only the species-specific samples in litter traps $(P<0.010)$, but also that of bulk litter collected at the forest floor $(P=$ 0.020). Thus, trees with higher $P$ concentrations in the canopy imparted a $\mathrm{P}$ signal on the bulk litter beneath their crowns. Canopy $\mathrm{P}$ was not related to soil $\mathrm{P}$; however, leaf litter $\mathrm{P}$ concentrations did significantly correlate with soil labile $\mathrm{P}$ concentrations $(P=0.039)$. Thus, bulk leaf litter $\mathrm{P}$ was correlated with both canopy $\mathrm{P}$ and soil labile $\mathrm{P}$ concentrations.

Concentrations of both total $\mathrm{C}$ and total $\mathrm{N}$ were significantly correlated between the canopy and litter trap leaves of individual trees $(P<0.001$ and $P=0.003$, respectively), but neither total $\mathrm{C}$ nor $\mathrm{N}$ concentrations of canopy leaves correlated with those of bulk leaf litter $(P=0.184$ and 0.267 , respectively). Neither were leaf litter total $\mathrm{C}$ nor total $\mathrm{N}$ values correlated with soil TOC or TDN values.

\section{DisCUSSION}

Our data suggest that traits of canopy tree species regulate free-living $\mathrm{N}$ fixation in this lowland tropical forest. Rates varied by species not only on canopy leaves (Fig. 2A) and recently senesced leaves, but also in both bulk leaf litter and soils within the crown radius of a given tree species (Fig. 2B, C). Thus, despite the fact that bulk litter and soils at any point in the forest reflect both the influence of multiple trees and soil fauna (that effectively mix and transport organic material), a significant "sphere of influence" persists for free-living $\mathrm{N}$ fixation. This finding is reminiscent of Zinke's (1962) classic study from a sand dune ecosystem suggesting that individual trees create species-specific footprints in soil properties, a phenomenon now shown in several temperate forest systems (Binkley et al. 1995, Binkley and Giardina 1998, van Breemen and Finzi 1998, Lovett et al. 2004, Hobbie et al. 2006).

Plant species effects on ecosystem function are not necessarily surprising. Some of the clearest examples of this potential come from the invasion literature, where introduction of symbiotic N fixers (Vitousek et al. 1987, Hughes and Denslow 2005), species with novel wateruse characteristics (Walker and Smith 1997), those that 


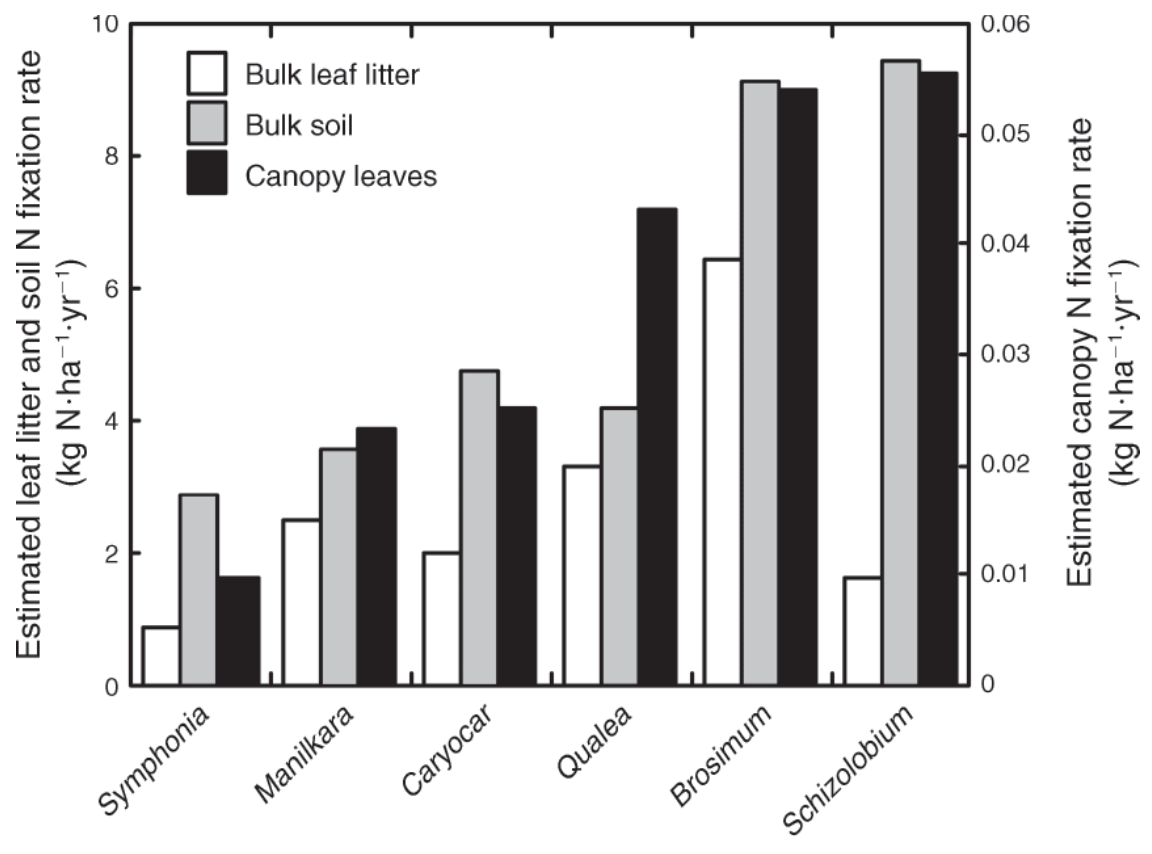

Genus

FIG. 4. Interspecific comparisons of area-based $\mathrm{N}$ fixation rates for each layer of the vertical profile. Spatially explicit values incorporate species differences in physical leaf properties (e.g., mass-to-area relationships), as well as facilitate comparisons with other studies; however, rates are estimated from a single sampling time and do not represent a definitive annual assessment of freeliving $\mathrm{N}$ inputs to this forest.

alter fire regimes (Mack and D'Antonio 1998), or even ones with simply high growth rates and/or nutrient-rich litter (Baruch and Goldstein 1999, Mack et al. 2000, Allison and Vitousek 2004) all have the potential to alter fundamental biogeochemical processes. Moreover, species manipulation studies suggest that tropical trees can differently affect a range of important ecosystem properties, including soil $\mathrm{C}$ storage (Russell et al. 2006), rates of $\mathrm{N}$ turnover and loss (Bigelow et al. 2004, Ewel 2006) and soil chemistry, among others (Montagnini and Sancho 1990, Ewel et al. 1991). However, in diverse tropical forests, it has been suggested that tree-specific traits will quickly "average out" across the landscape, and that the footprint of a given tree on the litter and soils beneath may be small (Powers et al. 2004, John et al. 2007). Many such studies have focused on bulk soil chemical indices alone, but we suggest processes that are more dynamic at short time scales, such as land-atmosphere-water exchanges of $\mathrm{C}$ and $\mathrm{N}$, may be most sensitive to the unique chemical properties of a given tree species.

Moreover, in contrast to Powers et al. (2004), in this forest we did find significant differences in soil $\mathrm{P}$ availability (as well as in bulk leaf litter $\mathrm{P}$ content) across species (Table 1), as well as a significant correlation between the $\mathrm{P}$ concentrations of canopy leaves and bulk leaf litter, suggesting a canopy footprint that does extend to forest floor nutrient availability. Furthermore, differences in $\mathrm{P}$ availability within each layer of our vertical sampling profile (canopy-to-soil) explained a significant fraction of the variability in $\mathrm{N}$ fixation (Fig. 3). The importance of $\mathrm{P}$ availability in regulating $\mathrm{N}$ fixation rates in this ecosystem is supported by data from $\mathrm{N}$ and $\mathrm{P}$ fertilization plots, where $\mathrm{P}$ additions significantly increased rates of soil and leaf litter $\mathrm{N}$ fixation (Reed et al. 2007). Perhaps not surprisingly, the strength of the relationship between $\mathrm{P}$ and $\mathrm{N}$ fixation declined from canopy to soil, reflecting both a dilution of individual species effects and the growing importance of other controls at the forest floor. Nonetheless, it is notable that species-specific variations in canopy $\mathrm{P}$ values retain a signal at the forest floor (Table 1), and still explain a significant portion of the variance in $\mathrm{N}$ fixation rates (Fig. 3).

We also observed substantial variation in $\mathrm{N}$ fixation rates along the canopy-to-soil gradient (Fig. 1), with strikingly high rates in bulk leaf litter, much lower rates in soil (on a mass basis), and the lowest rates of all on canopy leaves. Some early work estimated that canopy $\mathrm{N}$ fixation alone may add $>60 \mathrm{~kg} \mathrm{~N} \cdot \mathrm{ha}^{-1} \cdot \mathrm{yr}^{-1}$ to rain forest ecosystems (e.g., Edmisten 1970), while more recent work places these inputs at 2 to $5 \mathrm{~kg} \mathrm{~N} \cdot \mathrm{ha}^{-1} \cdot \mathrm{yr}^{-1}$ (Freiberg 1998, Benner et al. 2007). Yet, the rates of canopy $\mathrm{N}$ fixation we observed were significantly lower still, averaging $0.035 \mathrm{~kg} \mathrm{~N} \cdot \mathrm{ha}^{-1} \cdot \mathrm{yr}^{-1}$ (Fig. 4), a rate closer to the Goosem and Lamb (1986) estimate of 0.5 $\mathrm{kg} \mathrm{N} \cdot \mathrm{ha}^{-1} \cdot \mathrm{yr}^{-1}$. Collectively, estimates of rain forest canopy $\mathrm{N}$ fixation span four orders of magnitude, a discrepancy that highlights both the likely spatial and 
seasonal variability in canopy $\mathrm{N}$ fixation, and the need for far more data than are currently available.

In contrast to the species-specific patterns within each layer of the vertical profile (Fig. 3), P variability did not explain differences in $\mathrm{N}$ fixation rates along the vertical axis. This is not necessarily unexpected, as marked changes in controls over $\mathrm{N}$ fixation are likely along this gradient, and such controls may include not only variations in moisture and/or oxygen availability (Reed et al. 2007), but also variation in the composition of the microbial N-fixing community (Reed 2007). For example, $\mathrm{N}$ fixation rates were significantly higher in canopy leaves that were incubated under elevated PAR relative to those incubated on the forest floor $(0.49 \pm 0.15$ and $0.21 \pm 0.05 \mathrm{ng} \cdot \mathrm{g}^{-1} \cdot \mathrm{h}^{-1}$, respectively; $P<0.05$; Fig. 1 ), but neither leaf litter nor soil showed higher $\mathrm{N}$ fixation rates under elevated PAR. Thus, canopy $\mathrm{N}$-fixing communities may be dominated by autotrophic organisms, while forest floor communities are dominated by heterotrophic $\mathrm{N}$ fixers.

Furthermore, the relatively high $\mathrm{N}$ fixation rates in soil, and especially in bulk litter, may indicate zones of $\mathrm{N}$ limitation in this forest that are variable in both space and time. While lowland tropical forests are often thought to be $\mathrm{N}$ rich (e.g., Martinelli et al. 1999), several recent studies suggest that $\mathrm{N}$ demand may exceed supply in such forests (Ilstedt and Singh 2005, Cleveland and Townsend 2006). In particular, very wet forests, like the one studied here, are likely to experience exceptionally high rates of $\mathrm{N}$ loss via leaching and denitrification (e.g., Houlton et al. 2006), thereby perpetuating $\mathrm{N}$ deficits even in systems where $\mathrm{N}$ inputs may be substantial. In fact, given the potential for $\mathrm{N}$ losses, the high rates of $\mathrm{N}$ fixation we observed in soil and litter may be critical to meeting high $\mathrm{N}$ demand.

Finally, while we note that a one-time sampling must be interpreted with some caution, the potential clearly exists for variations in tree species to cause significant local-scale variation in $\mathrm{N}$ inputs from free-living $\mathrm{N}$ fixation. Rates in both this study and a year-round assessment of litter and soil $\mathrm{N}$ fixation values (Reed et al. 2007) are not trivial, and substantially exceed those typically found in higher latitude ecosystems (Cleveland et al. 1999). When canopy, litter, and soil values for this study are summed by tree species, estimates of annual rates vary by more than three-fold, and reach $\sim 15$ $\mathrm{kg} \cdot \mathrm{ha}^{-1} \cdot \mathrm{yr}^{-1}$ (Fig. 4). In addition, it's striking that when $\mathrm{N}$ fixation rates are converted to an area basis, there is remarkable correspondence among canopy, litter and soil rates across the six species (Fig. 4). The only deviation from this pattern is for bulk litter beneath $S$. parahyba, a legume that contains exceptionally soluble and rapidly decomposing litter (Wieder et al. 2008). Thus, we suggest that the notable variation among tropical tree species foliar chemistry (Townsend et al. 2007) may translate into significant local-scale variation in biogeochemical processes not only in the canopy itself, but in underlying litter and soils as well.
In summary, data from this study provide evidence that tree species in a diverse tropical rain forest may affect the rates of free-living $\mathrm{N}$ fixation occurring on and beneath them, and suggest that interspecific differences in $\mathrm{P}$ availability are an important factor in driving tree species effects. As discussed repeatedly in the current debate over the role of biodiversity in ecosystem function (Huston 1997, Chapin et al. 2000, Loreau et al. 2001, Hooper et al. 2005, Balvanera et al. 2006), local-scale species information may be critical for accurate predictions of ecosystem responses to environmental change. Our data show that this statement may extend to highly diverse tropical forests, as well as suggest that an ability to distill the complexity of rain forests into tractable relationships could prove essential in predicting changes to ecosystem function. However, our understanding of diversity-function relationships in such systems remains in its infancy.

ACKNOWLEDGMENTS

We are grateful to Tim Seastedt, Jason Neff, Bill Bowman, Steve Schmidt, and Nataly Ascarrunz for discussions that helped shape this research. We thank Will Wieder and Andres Vega for help in the field and Justin Feis, John Best, Rachael Zacks, Nataly Ascarrunz, and Will Wieder for laboratory assistance. Herbert and Marleny Michaud of the Drake Bay Wilderness Resort greatly assisted us with field access and logistical support in Costa Rica. We also thank Francisco Campos and the Organization for Tropical Studies and the Ministerio de Ambiente y Energia (MINAE) in Costa Rica for their help with permits and logistics. This work was supported by the National Science Foundation (NSF Grant DEB-0136957 to A. Townsend and C. Cleveland, NSF DDIG Grant DEB0710404 to A. Townsend and S. Reed, and a NSF Graduate Research Fellowship to S. Reed).

\section{Literature Cited}

Allison, S. D., and P. M. Vitousek. 2004. Rapid nutrient cycling in leaf litter from invasive plants in Hawai'i. Oecologia 141: 612-619.

Asner, G. P., J. M. O. Scurlock, and J. A. Hicke. 2003. Global synthesis of leaf area index observations: Implications of ecological and remote sensing studies. Global Ecology and Biogeography 12:191-205.

Balvanera, P., A. B. Pfisterer, N. Buchmann, J. S. He, T. Nakashizuka, D. Raffaelli, and B. Schmid. 2006. Quantifying the evidence for biodiversity effects on ecosystem functioning and services. Ecology Letters 9:1146-1156.

Baruch, Z., and G. Goldstein. 1999. Leaf construction cost, nutrient concentration, and net $\mathrm{CO}_{2}$ assimilation of native and invasive species in Hawaii. Oecologia 121:183-192.

Belnap, J. 1996. Soil surface disturbance in cold deserts: Effects on nitrogenase activity in cyanobacterial-lichen soil crusts. Biology and Fertility of Soils 23:362-367.

Benner, J. W., S. Conroy, C. K. Lunch, N. Toyoda, and P. M. Vitousek. 2007. Phosphorus fertilization increases the abundance and nitrogenase activity of the cyanolichen Pseudocyphellaria crocata in Hawaiian montane forests. Biotropica 39: 400-405.

Bern, C. R., A. R. Townsend, and G. L. Farmer. 2005. Unexpected dominance of parent material strontium in a tropical forest on highly weathered soils. Ecology 86:626632.

Berrange, J. P., and R. S. Thorpe. 1988. The geology, geochemistry and emplacement of the cretaceous tertiary 
ophiolitic Nicoya complex of the Osa Peninsula, southern Costa Rica. Tectonophysics 147:193-199.

Bigelow, S. W., J. J. Ewel, and J. P. Haggar. 2004. Enhancing nutrient retention in tropical tree plantations: No short cuts. Ecological Applications 14:28-46.

Binkley, D., and C. Giardina. 1998. Why do species affect soils? The warp and woof of tree-soil interactions. Biogeochemistry 32:89-106.

Binkley, D., F. W. Smith, and Y. Son. 1995. Nutrient supply and declines in leaf-area and production in lodgepole pine. Canadian Journal of Forestry Research 25:621-628.

Bowman, R. A., S. R. Olson, and F. S. Watanabe. 1978. Greenhouse evaluation of residual phosphate by four phosphorus methods in neutral and calcareous soils. Soil Science Society of America Journal 42:451-454.

Chapin, F. S., E. S. Zavaleta, V. T. Eviner, R. L. Naylor, P. M. Vitousek, H. L. Reynolds, D. U. Hooper, S. Lavorel, O. E. Sala, S. E. Hobbie, M. C. Mack, and S. Diaz. 2000. Consequence of changing biodiversity. Nature 405:234-242.

Clark, D. A. 2007. Detecting tropical forests' responses to global climatic and atmospheric change: current challenges and a way forward. Biotropica 39:4-19.

Cleveland, C. C., J. C. Neff, A. R. Townsend, and E. Hood. 2004. Composition, dynamics, and fate of leached dissolved organic matter in terrestrial ecosystems: results from a decomposition experiment. Ecosystems 7:275-285.

Cleveland, C. C., and A. R. Townsend. 2006. Nutrient additions to a tropical rain forest drive substantial carbon dioxide losses to the atmosphere. Proceedings of the National Academy of Sciences (USA) 104:10316-10321.

Cleveland, C. C., A. R. Townsend, D. S. Schimel, H. Fisher, R. W. Howarth, L. O. Hedin, S. S. Perakis, E. F. Latty, J. C. von Fischer, A. Elseroad, and M. Wasson. 1999. Global patterns of terrestrial biological nitrogen $\left(\mathrm{N}_{2}\right)$ fixation in natural ecosystems. Global Biogeochemical Cycles 13:623645.

Crews, T. E. 1999. The presence of nitrogen fixing legumes in terrestrial communities: evolutionary vs. ecological considerations. Biogeochemistry 46:233-246.

Crews, T. E., H. Farrington, and P. M. Vitousek. 2000. Changes in asymbiotic, heterotrophic nitrogen fixation on leaf litter of Metrosideros polymorpha with long-term ecosystem development in Hawaii. Ecosystems 3:386-395.

Edmisten, J. 1970. Preliminary studies of the nitrogen budget of a tropical rain forest. Pages $\mathrm{H} 211-\mathrm{H} 216$ in $\mathrm{H}$. T. Odum and R. F. Pegeon, editors. A tropical rain forest: a study of irradiation and ecology at El Verde, Puerto Rico. U.S. Atomic Energy Commission, Springfield, Massachusetts, USA.

Eisele, K. A., D. S. Schimel, L. A. Kapsutka, and W. J. Parton. 1989. Effects of available phosphorus and nitrogenphosphorus ratios on non-symbiotic dinitrogen fixation in tallgrass prairie soils. Oecologia 79:471-474.

Ewel, J. J. 2006. Species and rotation frequency influence soil nitrogen in simplified tropical plant communities. Ecological Applications 16:490-502.

Ewel, J. J., M. J. Mazzarino, and C. W. Berish. 1991. Tropical soil fertility changes under moncultures and successional communities of different structure. Ecological Applications $1: 289-302$.

Freiberg, E. 1998. Microclimatic parameters influencing nitrogen fixation in the phyllosphere of a Costa Rican premontane rain forest. Oecologia 17:9-18.

Galloway, J. N., W. H. Schlesinger, H. Levy, A. Michaels, and J. L. Schnoor. 1995. Nitrogen fixation: Anthropogenic enhancement-environmental Response. Global Biogeochemical Cycles 9:235-252.

Galloway, J. N., et al. 2004. Nitrogen cycles: past, present and future. Biogeochemistry 70:153-166.

Gehring, C., P. L. G. Vlek, L. A. G. de Souza, and M. Denich. 2005. Biological nitrogen fixation in secondary regrowth and mature rain forests of central Amazonia. Agriculture, Ecosystems, and Environment 111:237-252.

Goosem, S., and D. Lamb. 1986. Measurements of phyllosphere nitrogen fixation in a tropical and two sub-tropical rain forests. Journal of Tropical Ecology 2:373-376.

Hardy, R. W. F., R. D. Holsten, E. K. Jackson, and R. C. Burns. 1968. The acetylene-ethylene assay for $\mathrm{N}_{2}$ fixation: laboratory and field evaluation. Plant Physiology 43:1185-1207.

Hartshorn, G. S., and L. J. Poveda. 1983. Checklist of trees. Pages 158-183 in D. H. Janzen, editor. Costa Rican natural history. University of Chicago Press, Chicago, Illinois, USA.

Hicks, W. T., M. E. Harmon, and R. P. Griffiths. 2003. Abiotic controls on nitrogen fixation and respiration in selected woody debris from the Pacific Northwest, U.S.A. Ecoscience 10:66-73.

Hobbie, S. E., and L. Gough. 2004. Litter decomposition in moist acidic and non-acidic tundra with different glacial histories. Oecologia 140:113-124.

Hobbie, S. E., P. B. Reich, J. Oleksyn, M. Ogdahl, R. Zytkowiak, C. Hale, and P. Karolewski. 2006. Tree species effects on decomposition and forest floor dynamics in a common garden. Ecology 87:2288-2297.

Holdridge, L. R., W. C. Grenke, W. H. Hatheway, T. Lian, and J. A. Tosi. 1971. Forest environments in tropical life zones: a pilot study. Oxford Pergamon Press, Oxford, UK.

Hooper, D. U., et al. 2005. Effects of biodiversity on ecosystem functioning: a consensus of current knowledge. Ecological Monographs 75:3-35.

Houlton, B. Z., D. M. Sigman, and L. O. Hedin. 2006. Isotopic evidence for large gaseous nitrogen losses from tropical rainforests. Proceedings of the National Academy of Sciences (USA) 103:8745-8750.

Hughes, R. F., and J. S. Denslow. 2005. Invasion by a $\mathrm{N}_{2}$-fixing tree alters function and structure in wet lowland forests of Hawaii. Ecological Applications 15:1615-1628.

Huston, M. A. 1997. Hidden treatments in ecological experiments: re-evaluating the ecosystem function of biodiversity. Oecologia 110:449-460.

Ilstedt, U., and S. Singh. 2005. Nitrogen and phosphorus limitations of microbial respiration in a tropical phosphorusfixing acrisol (ultisol) compared with organic compost. Soil Biology and Biochemistry 37:1407-1410.

John, R. J., W. Dalling, K. E. Harms, J. B. Yavitt, R. F. Stallard, M. Mirabello, S. P. Hubbell, R. Valencia, H. Navarrete, M. Vallejo, and R. B. Foster. 2007. Soil nutrients influence spatial distributions of tropical tree species. Proceedings of the National Academy of Sciences (USA) 104:864-869.

Jordan, C. W., W. Caskey, G. Escalante, R. Herrera, F. Montagnini, R. Todd, and C. Uhl. 1982. The nitrogen cycle in a "Terra Firme" rain forest on oxisol in the Amazon Territory of Venezuela. Plant and Soil 67:325-332.

Kalbitz, K., S. Solinger, J. H. Park, B. Michalzik, and E. Matzner. 2000. Controls on the dynamics of dissolved organic matter in soils: a review. Soil Science 165:277-304.

Kappelle, M., M. Castro, H. Acevedo, L. González, and H. Monge. 2002. Ecosystems of the Osa Conservation Area (ACOSA). Instituto Nacional Biodiversidad (INBio), Santo Domingo de Heredia, Costa Rica.

Kreibich, H. 2002. N2 fixation and denitrification in a floodplain forest in Central Amazonia, Brazil. Dissertation. Philipps-University of Marburg, Marburg, Germany.

Kreibich, H., and J. Kern. 2003. Nitrogen fixation and denitrification in a floodplain forest near Manaus, Brazil. Hydrological Processes 17:1431-1441.

Kuo, S. 1996. Phosphorus. Pages 869-919 in D. L. Sparks, editor. Methods of soil analysis. Part 3: chemical methods. Soil Society of America, Madison, Wisconsin, USA.

Ley, R. E., and C. M. D’Antonio. 1998. Exotic grass invasion alters potential rates of $\mathrm{N}$ fixation in Hawaiian woodlands. Oecologia 113:179-187. 
Loreau, M., S. Naeem, P. Inchausti, J. Bengtsson, J. P. Grime, A. Hector, D. U. Hooper, M. A. Huston, D. Raffaelli, B. Schmid, D. Tilman, and D. A. Wardle. 2001. Biodiversity and ecosystem functioning: current knowledge and future challenges. Science 294:804-808.

Lovett, G. M., K. C. Weathers, M. A. Arthur, and J. C. Schultz. 2004. Nitrogen cycling in a northern hardwood forest: Do species matter? Biogeochemistry 67:289-308.

Mack, M. C., and C. M. D'Antonio. 1998. Impacts of biological invasions on disturbance regimes. Trends in Ecology and Evolution 13:195-198.

Mack, R. N., D. Simberloff, W. M. Lonsdale, H. Evans, M. Clout, and F. A. Bazzaz. 2000. Biotic invasions: causes, epidemiology, global consequences, and control. Ecological Applications 10:680-710.

Maheswaran, J., and A. U. N. Gunatilleke. 1990. Nitrogenase activity in soil and litter of a tropical lowland rain forest and adjacent fernland in Sri Lanka. Journal of Tropical Ecology 6:281-289.

Martinelli, L. A., M. C. Piccolo, A. R. Townsend, P. M. Vitousek, E. Cuevas, W. McDowell, G. P. Roberston, O. C Santos, and K. Treseder. 1999. Nitrogen stable isotopic composition of leaves and soil: tropical versus temperate forests. Biogeochemistry 46:45-65.

Matson, P. A., K. Lohse, and S. Hall. 2002. The globalization of nitrogen deposition: consequences for terrestrial ecosystems. Ambio 31:113-119.

Montagnini, F., and F. Sancho. 1990. Impacts of native trees on tropical soils: a study in the Atlantic lowlands of Costa Rica. Ambio 19:386-390.

Neff, J. C., F. S. Chapin, III, and P. M. Vitousek. 2003. Breaks in the cycle: dissolved organic nitrogen in terrestrial ecosystems. Frontiers in Ecology and the Environment 1: 205-211.

Powers, J. S., M. H. Kalicin, and M. E. Newman. 2004. Tree species do not influence local soil chemistry in a species-rich Costa Rica rain forest. Journal of Tropical Ecology 20:587590.

Reed, S. C. 2007. Scaling from molecules to ecosystems: controls over free-living nitrogen fixation in terrestrial ecosystems. Dissertation. University of Colorado at Boulder, Boulder, Colorado, USA.

Reed, S. C., C. C. Cleveland, and A. R. Townsend. 2007. Controls over leaf litter and soil nitrogen fixation in two lowland tropical rain forests. Biotropica 39:585-592.

Remacle, J. 1977. Microbial transformation of nitrogen in forests. Oecologia Plantarum 12:33-43.

Richards, B. N. 1973. Nitrogen fixation in the rhizosphere of conifers. Soil Biology and Biochemistry 5:149-152.

Robertson, G. P., D. Wedin, P. M. Groffman, J. M. Blair, E. M. Holland, K. J. Nadelhoffer, and D. Harris. 1999. Soil carbon and nitrogen availability: nitrogen mineralization and soil respiration potentials. Pages $258-271$ in G. P. Robertson, D. C. Coleman, C. S. Bledsoe, and P. Sollins, Standard methods of long-term ecological research. Oxford University Press, New York, New York, USA.
Roskoski, J. P. 1980. Nitrogen fixation in hardwood forests of the northeastern United States. Plant and Soil 54:33-44.

Russell, A. E., C. A. Cambardella, J. J. Ewel, and T. B. Parkin. 2006. Species, rotation, and life-form diversity effects on soil carbon in experimental tropical systems. Ecological Applications $14: 47-60$.

Silvester, W. B. 1978. Nitrogen fixation and mineralization in a Kauri (Agathis australis) forest in New Zealand. Pages 138143 in M. W. Loutit and J. A. R. Miles, editors. Microbial ecology. Springer-Verlag, Berlin, Germany.

Sprent, J. I., and P. Sprent. 1990. Nitrogen fixing organisms. Chapman and Hall, London, UK.

Tiessen, H., and J. O. Moir. 1993. Characterization of available $\mathrm{P}$ by sequential extraction. Pages $75-86$ in M. R. Carder, editor. Soil sampling and methods of analysis. Lewis Publishers, Boca Raton, Florida, USA.

Townsend, A. R., C. C. Cleveland, G. P. Asner, and M. M. C. Bustamante. 2007. Controls over foliar N:P ratios in tropical rain forests. Ecology 88:107-118.

van Breemen, N., and A. C. Finzi. 1998. Plant-soil interactions: ecological aspects and evolutionary implications. Biogeochemistry 42:1-19.

Vitousek, P. M. 1994. Potential nitrogen fixation during primary succession in Hawaii Volcanoes National Park. Biotropica 26:234-240.

Vitousek, P. M., J. D. Aber, R. W. Howarth, G. E. Likens, P. A. Matson, D. W. Schindler, W. H. Schlesinger, and D. G. Tilman. 1997. Human alteration of the global nitrogen cycle: sources and consequences. Ecological Applications 7:737-750.

Vitousek, P. M., K. Cassman, C. C. Cleveland, T. Crews, C. B. Field, N. B. Grimm, R. W. Howarth, R. Marino, L. Martinelli, E. B. Rastetter, and J. I. Sprent. 2002. Towards an ecological understanding of biological nitrogen fixation. Biogeochemistry 57:1-45.

Vitousek, P., and S. Hobbie. 2000. Heterotrophic nitrogen fixation in decomposing litter: patterns, mechanisms, and models. Ecology 75:418-429.

Vitousek, P. M., and R. W. Howarth. 1991. Nitrogen limitation on land and in the sea: How can it occur? Biogeochemistry 13:87-115.

Vitousek, P. M., L. R. Walker, L. D. Whiteaker, D. MuellerDombois, and P. A. Matson. 1987. Biological invasion by Myrica faya alters ecosystem development in Hawaii. Science 238:802-804.

Walker, L. R., and S. D. Smith. 1997. Impacts of invasive plants on community and ecosystem properties. Pages 69-86 in J. O. Luken and J. W. Thieret, Assessment and management of plant invasions. Springer-Verlag, New York, New York, USA.

Wieder, W. W., C. C. Cleveland, and A. R. Townsend. 2008. Tropical tree species composition affects the oxidation of dissolved organic matter from litter. Biogeochemistry 88: $127-138$.

Zinke, P. J. 1962. Pattern of influence of individual forest trees on soil properties. Ecology 43:130-133. 